\title{
Variations in platelet count and total protein in relation to differences in sex, age, breed and reproductive status of goats during the cold-dry season (harmattan)
}

\begin{abstract}
This study aimed at evaluating the effect of sex, age, breed and reproductive status on platelet count and total protein, and also to demonstrate the relationship between the two variables in goats during the cold-dry season. At the peak of the cold-dry season, 56 male and female goats belonging to Red Sokoto $(\mathrm{n}=28)$ and Sahel $(\mathrm{n}=28)$ as well as 14 Red Sokoto goats in the last trimester of gestation $(n=7)$ and early lactation $(n=7)$ were sampled and results statistically analysed. The results revealed that the platelet count was significantly $(\mathrm{P}<0.05)$ higher in kids, bucks, Red Sokoto and pregnant goats, while blood total protein was significantly lower $(\mathrm{P}<0.05)$ in kids, bucks, Red Sokoto and pregnant goats. In addition to this inverse relationship, a significantly negative correlation $(\mathrm{P}<0.005 ; \mathrm{r}=-0.330)$ was observed between platelet and blood total protein It was concluded that sex, age, breed and reproductive status markedly influenced platelet count and blood total protein in an inverse manner with a negative correlation between the two variables in goats exposed to a season with low ambient temperature. More studies are needed to directly establish and understand the relationship between platelet count and blood total protein on exposure to low ambient temperature so as to explore its effect on animal health, particularly during the peri-partum period and its benefit in individuals with haemostatic challenges.
\end{abstract}

Keywords: cold-dry season, red sokoto goats, sahel goats, pregnant goats, low ambient temperature
Volume 5 Issue 3 - 2017

\author{
Habibu B, 'Abdullahi A,' Yaqub LS,' Makun \\ $\mathrm{H}$, ${ }^{2}$ Kawu MU,'Ahmadu $\mathrm{S}^{3}$ \\ 'Department of Veterinary Physiology,Ahmadu Bello University, \\ Nigeria \\ ${ }^{2}$ Ahmadu Bello University, Nigeria \\ ${ }^{3}$ Universiti Sultan Zainal Abidin, Asia
}

Correspondence: B Habibu, Department of Veterinary Physiology, Ahmadu Bello University, Zaria, Nigeria, Tel +2348069092685, Email buharihabibu@rocketmail.com

Received: March 31, 2017| Published: April 26, 2017

\section{Introduction}

Tropical animals are poorly adapted to the low ambient temperature and hypothermia may result even at ambient temperature of $15-12^{\circ} \mathrm{C}$ during the cold season. ${ }^{1,2}$ Hypothermia has been shown to cause thrombocytopenia, slowing down of coagulation enzymes, disordered fibrinolysis, and disruption of platelet function; and thus, may negatively affect the hemostasis. ${ }^{3,4}$ This may pose a challenge to haemostasis during parturition and injury which are characterised by excessive bleeding., ${ }^{4,5}$ The blood coagulation system involves the interaction between platelet and blood proteins through three basic elements: platelet adhesion, activation and aggregation, fibrin formation, and fibrinolysis. ${ }^{6}$ There are 20 blood clotting proteins (coagulation factor) found in the blood. When a blood vessel is damaged, these clotting factors are switched on in a cascade manner which results in the formation of a clot. If one of the factors is absent or present at low levels, blood clotting challenges may ensue. ${ }^{7,8}$

Haematological parameters are commonly determined to evaluate the health status of animals and studying the effect of sex, age, breed, reproductive status and season on haematological parameters is important in providing clinical and research guide during interpretation and decision making. ${ }^{9,10}$ Despite the importance of platelets in mediating both innate and adaptive immune system ${ }^{11}$ and their role in blood clotting, platelets count is not commonly evaluated in studies involving manual determination of haematological parameters, probably due to cost and complexity of the technique. This has led to a dearth of information on platelet count and expected variation in different animals. Haemostatic profile is commonly evaluated using platelet count, prothrombin time, activated partial thromboplastin time, fibrinogen level; ${ }^{5}$ as well as through parameters obtained from automated haematological counter, including mean platelet volume (MPV), platelet distribution width (PDW) and plateletcrit (PCT) or thrombocrit. ${ }^{12,13}$ Furthermore, determination of platelet count and blood fibrinogen concentration have been shown to be of great benefit during haemostatic challenges as these parameters have been reported to increase during parturition. ${ }^{5}$ Despite the fact that a number of blood total proteins including fibrinogen and clotting factors such as prothrombin, thromboplastin, fibronectin, antithrombin, heparin and plasminogen participate in haemostasis, till date, the relationship between total protein and platelet count has not been well documented. Thus, the aim of this study was to evaluate the effect of sex, age, breed and reproductive status on platelet count and total protein, and their relationship in goats exposed to low ambient temperature in a tropical environment.

\section{Materials and methods}

\section{Experimental site and animal management}

Animals used for the study were housed in well-ventilated pens belonging to the Small Ruminant Research Section of the National Animal Production Research Institute (NAPRI), Ahmadu Bello University, Shika, Zaria, located on latitude $11^{\circ} 12^{\prime} \mathrm{N}$, longitude $7^{\circ} 33^{\prime}$ $\mathrm{E}$, and altitude of $610 \mathrm{~m}$ above sea level. The health status of the goats was evaluated based on behaviour, rectal temperature, appetite and faecal consistency. Only clinically healthy animals were used for the 
study. Body condition was scored by the same person adopting a sixpoint scale method. ${ }^{14}$ Digitaria smutsi hay was provided as basal diet and concentrate ration comprising ground maize (30\%), cotton seed cake $(36 \%)$, maize offal $(20 \%)$, wheat offal $(10 \%)$, bone meal $(2.5 \%)$ and salt $(1.5 \%)$ at $3 \%$ body weight per day given as supplement Good-quality drinking water was provided Ad libitum. The study got an approval from the Ahmadu Bello University Committee on Animal Use and Welfare and the research followed the international guidelines for animal welfare.

\section{Experimental design, blood sample collection and analysis}

The study was conducted in the month of December during the cold-dry season (November- February), prevailing in Zaria, ${ }^{2,15}$ located in the Northern Guinea Savannah zone of Nigeria. A total of 70 goats sampled at the peak of the cold-dry season (December) were used for the study. Fifty-six (56) male and dry/non-pregnant female goats belonging to Red Sokoto $(n=28)$ and Sahel $(n=28)$ breeds were used to study the effect of breed, sex and age. From both breeds, kids $(n=14)$ of both sexes aged between 2 and 4 months with body weight ranging between $2-8 \mathrm{~kg}$, and adult goats of both sexes $(n=14)$ aged between 1.5 to 4years with body weight ranging between $20-25 \mathrm{~kg}$ were used during the study. To evaluate the effect of reproductive status, 14 pregnant $(n=7)$ and lactating $(n=7)$ goats belonging to the Red Sokoto breed were used. The does were oestrous-synchronised using CIDR such that the late gestation and early lactation periods occured at the peak of the cold-dry season. The pregnant does were synchronised in August, while the lactating does were synchronised in July. The pregnant does were sampled between days 135 and 140 (third trimester) of gestation and the lactating animals were sampled within the third week of lactation (early lactation period). All groups were balanced for age, body weight and body condition score.

Blood sample $(5 \mathrm{ml})$ was collected from the goat in the morning hours, between 09:00h $-10: 00 \mathrm{~h}(\mathrm{GMT}+1)$, through the jugular vein into vacutainer tubes containing potassium ethylenediaminetetraacetic acid ( $\mathrm{K}_{3}$ EDTA). Counting of the platelet was done manually using a haemocytometer (16), while the blood total protein was determined using a hand-held clinical refractometer (Atago ${ }^{\circledR}$, Master Refractometer, Japan).

\section{Environmental conditions and data analysis}

The minimum and maximum values of ambient temperature and relative humidity as well as wind speed recorded during the study period; were obtained from the Data Processing Unit, Institute of Agricultural Research, Ahmadu Bello University, Zaria, located about $5 \mathrm{~km}$ away from the experimental site. The data was obtained within the week (7days) the experiment was conducted.

The statistical package used for data analysis was Graph Pad Prism version 5.01 for windows (2007) from GraphPad software, San Diego California, USA (www. graphpad.com). Data analysed were expressed as mean $( \pm$ SEM). Comparisons between breeds, sexes and age groups were done using Student's $t$-test, while one-way analysis of variance, followed by Tukey's post-hoc test was used to compare values between the reproductive statuses. Values of $\mathrm{P}<0.05$ were considered significant.

\section{Results and discussion}

The mean ambient temperature (Table 1) recorded in the current study during the morning hours $\left(12-15^{\circ} \mathrm{C}\right)$ was lower than the thermoneutral zone of $25-\mathrm{s} 30^{\circ} \mathrm{C}$ reported for tropical goats. ${ }^{17}$ In agreement with previous observation, ${ }^{1}$ this suggests that the goats may have suffered from hypothermia during the morning hours of the cold-dry season.

\section{Effect of sex, age breed and reproductive status on pla- telet count}

Effects of sex and age on platelet count are presented on (Table 2 $\&$ Table 3$)$. Significantly $(\mathrm{P}<0.05)$ higher platelet count was observed in adult red Sokotobucks compared with does in the current study. Similarly, Egbe-Nwiyi et al. ${ }^{18}$ demonstrated higher platelet count in Sahelbucks compared with does. The high platelet count in the bucks may be attributed to thrombopoietic effect of testosterone, since castration has been reported to decrease platelet count in mice, while replacement therapy with testosterone restored platelet production. ${ }^{19}$

Table I Environment conditions during the experiment

\begin{tabular}{lllll}
\hline & $\mathbf{A T M i n}\left({ }^{\circ} \mathbf{C}\right)$ & $\mathbf{R H} \min (\%)$ & RHmax (\%) & WS (km/day) \\
\hline Mean \pm SEM & $13.00 \pm 0.45$ & $13.83 \pm 1.58$ & $19.33 \pm 1.33$ & $162.60 \pm 12.77$ \\
Range & $12.00-15.00$ & $8.00-20.00$ & $16.00-24.00$ & $135.30-215.50$
\end{tabular}

$\mathrm{AT}_{\text {Min }}$, minimum ambient temperature; $\mathrm{AT}_{\text {Max }}$, maximum ambient temperature; $\mathrm{RH}_{\text {min }}$, minimum relative humidity; $\mathrm{RH}_{\text {mix }}$, maximum relative humidity; $\mathrm{WS}$, wind speed

Table 2 Effect of sex and age on platelet count and blood total protein in Red Sokoto goats during the cold-dry seasons

\begin{tabular}{lllll}
\hline & \multicolumn{2}{l}{ Platelet count $(\mathrm{I} \mathrm{09/L})$} & \multicolumn{2}{l}{ Blood total protein $(\mathrm{g} / \mathrm{dL})$} \\
\cline { 2 - 5 } & Male & Female & Male & Female \\
\hline Young & $250.50 \pm 17.02$ & $249.60 \pm 25.77$ & $6.43 \pm 0.09^{\mathrm{x}}$ & $6.567 \pm 0.14^{\mathrm{x}}$ \\
Adult & $265.60 \pm 9.78^{\mathrm{a}}$ & $190.40 \pm 28.42^{\mathrm{b}}$ & $7.20 \pm 0.13^{y}$ & $7.85 \pm 0.53^{y}$ \\
Overall & $257.50 \pm 10.02$ & $227.10 \pm 20.13$ & $6.82 \pm 0.11^{\mathrm{a}}$ & $7.30 \pm 0.35^{\mathrm{b}}$ \\
\hline
\end{tabular}

Values with different alphabets are statistically significant $(P<0.05) . x, y$, between age group and a, b, between different sexes 
Table 3 Effect of sex and age on platelet count and blood total protein in Sahel goats during the cold-dry seasons

\begin{tabular}{lllll}
\hline & \multicolumn{2}{l}{ Platelet count $\left(10^{9} / \mathrm{L}\right)$} & \multicolumn{2}{l}{ Blood total protein $(\mathrm{g} / \mathrm{dL})$} \\
\cline { 2 - 5 } & Male & Female & Male & Female \\
\hline Young & $247.00 \pm 35.79^{x}$ & $206.00 \pm 27.91^{x}$ & $7.20 \pm 0.22$ & $6.24 \pm 0.43^{x}$ \\
Adult & $137.40 \pm 13.89^{y}$ & $158.70 \pm 28.59^{y}$ & $7.71 \pm 0.26$ & $7.97 \pm 0.38^{y}$ \\
Overall & $158.80 \pm 14.86$ & $195.50 \pm 25.03$ & $7.53 \pm 0.19$ & $7.25 \pm 0.37$
\end{tabular}

Values with different alphabets are statistically significant $(P<0.05) . x, y$, between age group

In Sahel breed of goats, higher $(\mathrm{P}<0.05)$ number of platelets was observed in kids compared with adults. Although data on the effect of age on platelet count of goats is scarce, other studies in sheep, ${ }^{20} \mathrm{dogs}^{13}$ and humans ${ }^{21}$ have sufficiently reported higher platelet count in the young compared with adults. In fact, a decrease of up to $35 \%$ in men and $25 \%$ in women as compared with the infancy has been reported. ${ }^{22}$ Although there is no proven explanation for these changes, the sharp decrease in thrombopoietin level from infancy to adulthood and reduction in haematopoietic stem cell reserve have been speculated to be responsible for the reduction in platelet count with age. ${ }^{21,23}$ In pigs, there was no significant change in platelet count and mean platelet volume, whereas, the PDW dramatically increase from birth to $12 \mathrm{~h}$ after birth. $^{12}$

Effect of breed on platelet count is presented on Figure 1 and the number of platelet was significantly higher $(\mathrm{P}<0.05)$ in Red Sokoto compared with Sahel goats. This contradicts the finding of Okonkwo et al. ${ }^{24}$ which reported no significant difference in platelet count between Red Sokoto and Sahel goats adapted to the tropical humid climate of Nigeria. Likewise, the values of platelet count were higher in the current study as compared to values recorded by Okonkwo et al. ${ }^{24}$ Differences in climate and season is likely responsible for this physiological variation. The breed variation in the current study is probably due to differences in the adaptation of the breeds to Guinea Savannah climate, since the Sahel goat is originally indigenous to the Sahel climate of West Africa, while the Red Sokoto goats are native to the study area. Breeds that are poorly adapted to cold may develop hypothermia on exposure to low ambient temperature which could predispose them to thrombocytopaenia. ${ }^{1,2,4}$

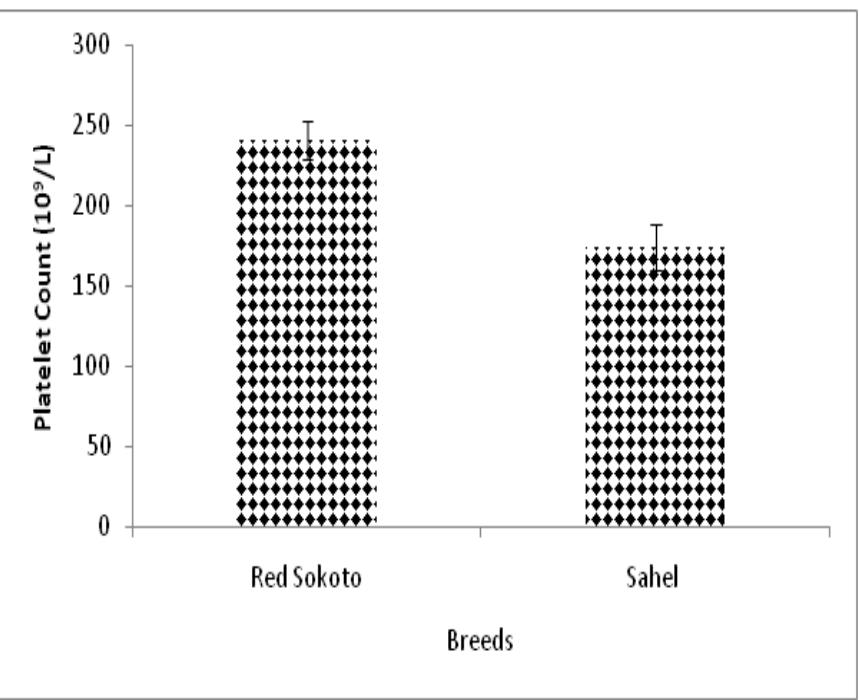

Figure I Effect of breed on platelet count in Red Sokoto and Sahel goats during the cold-dry season.
The platelet count was significantly higher in pregnant compared with non-pregnant goats (Figure 2). The number of platelets were maintained at relatively stable values during the gestation, but increased during foaling, and returned to pre-foaling level after foaling. ${ }^{5}$ The high platelet count during the third trimester of gestation in the current study may be a preconditioned physiological response to check the excessive blood loss from damaged vessels during parturition. In a similar study in sheep, the platelet count was markedly higher during gestation compared with the lactation period. ${ }^{25}$

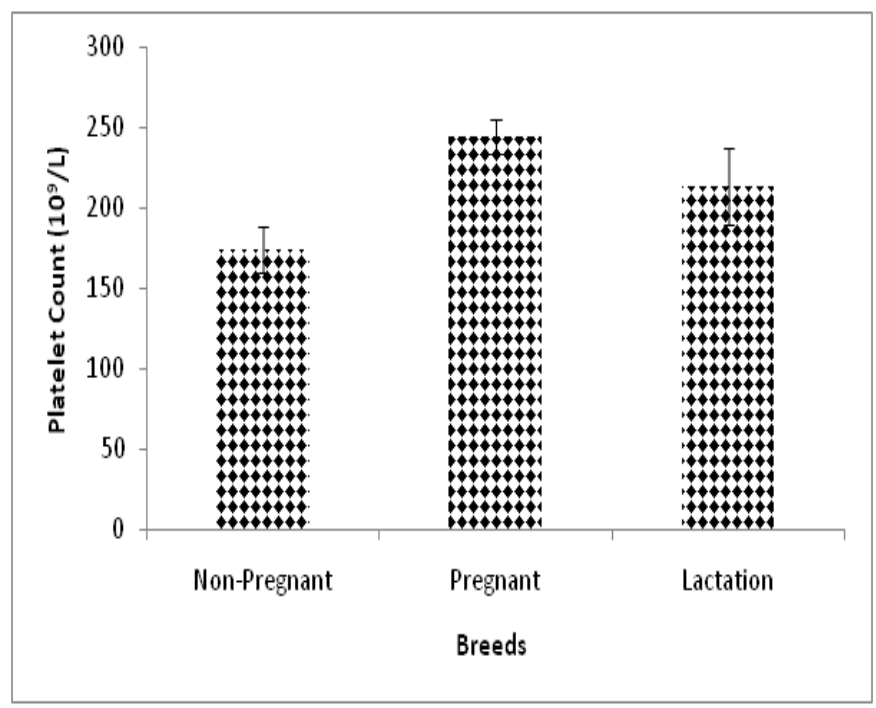

Figure 2 Effect of reproductive status on platelet count in Red Sokoto goats during the cold-dry season.

\section{Effect of sex, age, breed and reproductive status on blood total protein}

The mean values of blood total protein are presented in Table 1 \& Table 2 for Red Sokoto and Sahel goats, respectively. The values of blood total protein recorded in the current study were within the range reported by Byers \& Kramer. ${ }^{26}$ Significantly higher $(\mathrm{P}<0.05)$ blood total protein was observed in Red Sokoto does as compared with bucks. This agrees with the study of Al-Hadithy \& Badawi ${ }^{27}$ which reported higher blood total protein in female compared with male sheep. Irrespective of breed, mean value of blood total protein was significantly higher in adults goats compared with the kids. This finding agrees with previous reports in camels ${ }^{28}$ and buffaloes. ${ }^{29}$ The increase is attributed to elevation in the levels of albumin and $\gamma$-globulin. ${ }^{29}$ Higher uptake and utilization of dietary protein for growth and development in young animals as compared with adults may be responsible for the low blood total protein in goat kids. In addition, the immaturity of the lymphoid system in young animals may cause a reduction in blood globulin and thus, contribute to the 
low blood total protein in the young animals. ${ }^{30}$ Significantly $(\mathrm{P}<0.05)$ higher blood total protein in Sahel compared with Red Sokoto goats (Figure 3 ) agrees with another study in sheep. ${ }^{31}$ Similarly, this variation may be associated with differences in the adaptive responses of the two breeds.

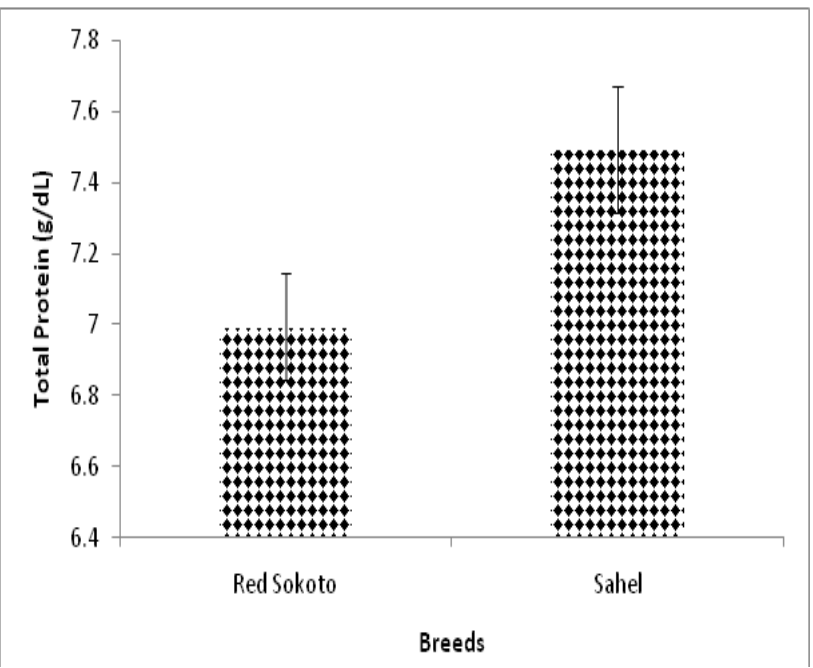

Figure 3 Effect of breed on blood total protein in Red Sokoto and Sahel goats during the cold-dry season.

Significantly lower values of blood total protein (Figure 4) were observed in pregnant compared with non-pregnant and lactating goats in the current studies. This is likely due to high foetal demand for protein and increased metabolic demand during the last trimester of gestation. ${ }^{32}$ Moreover, utilisation of serum globulins by the mammary glands for colostrum synthesis has also been implicated due to the corresponding decrease in globulin during gestation. ${ }^{33,34}$ However, an increase in blood total protein and globulin in the last week of the third trimester has been reported in goats with subsequent decline in both parameters in the second week of lactation. ${ }^{35}$ The marked fluctuation in blood total protein in different stages of gestation may explain why a previous study demonstrated higher blood total protein in pregnant compared with lactating ewes. ${ }^{25}$

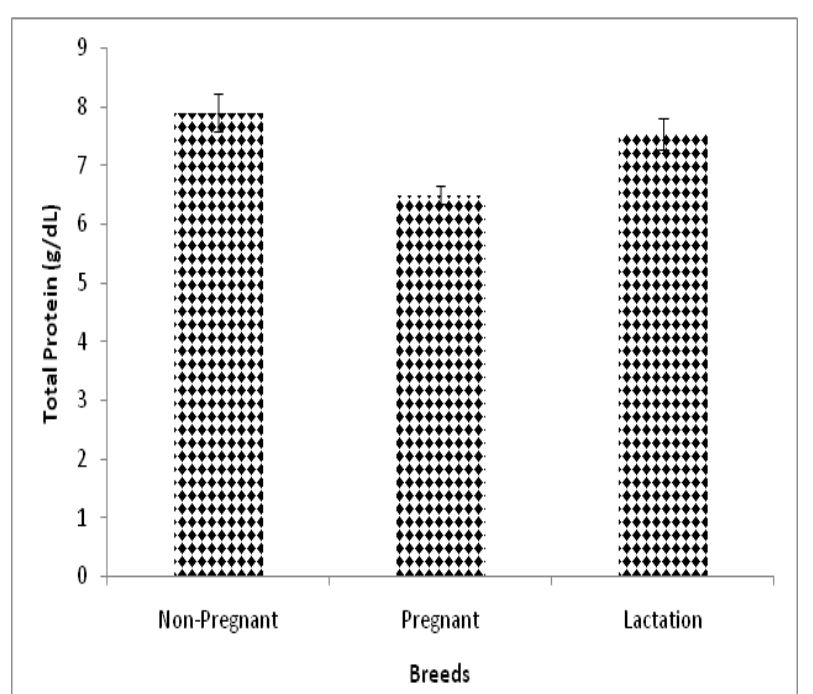

Figure 4 Effect of reproductive status on blood total protein in Red Sokoto goats during the cold-dry season.

\section{Relationship between platelet and blood total protein}

The relationship between platelet and blood total protein (Figure 5) indicates a significantly negative $(\mathrm{P}<0.005 ; \mathrm{r}=-0.330)$ correlation between platelet count and blood total protein. Similarly, an inverse pattern was observed on the influence of sex, age, breed and reproductive status on platelet count and blood total protein. For instance, while platelet count decreases with age, blood total protein increases with age. Also, platelet count was higher in Red Sokoto goats, but blood total protein was lower in Red Sokoto compared with Sahel goats. This pattern was also consistent in the variables observed in sex and reproductive status. This relationship needs further investigation. If established, and the parameter with the stronger influence identified, it may be possible to manipulate platelet number using dietary protein. Albumin, the most abundant total protein may be responsible for the pattern observed as it decreases the activity of platelets and its administration negatively correlated with platelet count. ${ }^{36-38}$ It is unknown whether an increase in blood albumin may suppress platelet release into circulation and vice versa; and if this physiological response is associated with exposure to low ambient temperature. Moreover, more studies are required to know if this apparently strong association between the two parameters is responsible for the pattern observed in the variation in sex, age, breed and reproductive status. However, it is worth noting that a previous study that evaluated the effect of reproductive status on platelet count and blood total protein in sheep did not observe such physiological response. ${ }^{25}$

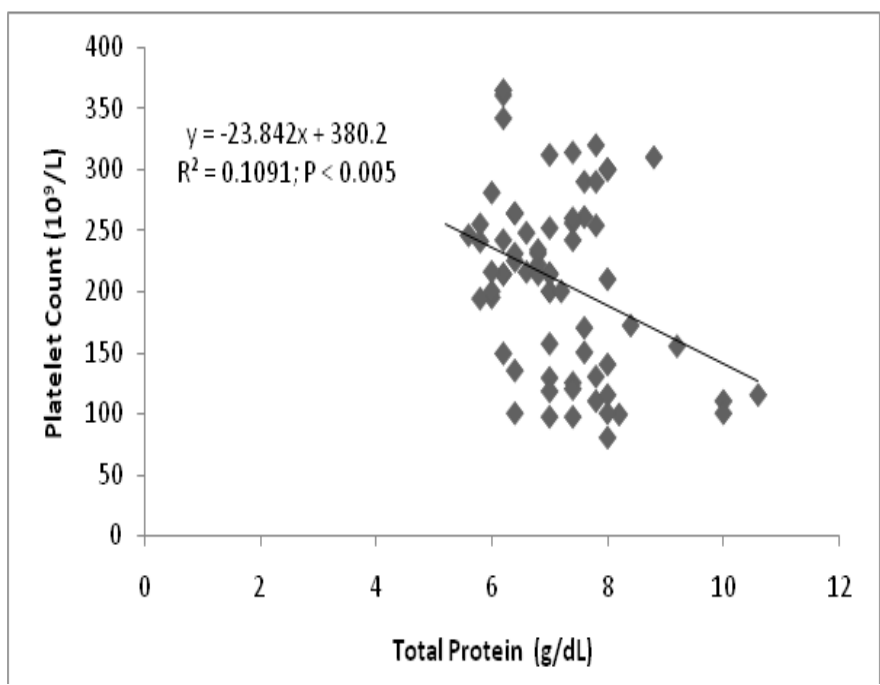

Figure 5 Relationship between platelet count and blood total protein in Red Sokoto and Sahel goats during the cold-dry season.

\section{Conclusion}

Sex, age, breed and reproductive status influence the platelet count and blood total protein in Red Sokoto and Sahel goats. Thus, this relationship should be considered in the management of haemostatic conditions, interpretation of research data and in the generation of reference values of these parameters in goats. However, more studies are needed to directly establish and understand the relationship between platelet counts and blood total protein; and to also investigate the role of exposure to low ambient temperature on this relationship, so as to explore its possible benefit in animal health and production and in individuals with haemostatic challenges. 


\section{Acknowledgements}

The Management of NAPRI, Ahmadu Bello University, Shika, Zaria, granted us the permission to use the institution's animals. The staff of the Small Ruminant Research Programme, NAPRI, and Department of Veterinary Physiology, Ahmadu Bello University, Zaria gave technical assistance. Also, Mal. Yunusa Bukar Muhammed and other staff of Veterinary Clinical Pathology Laboratory, Ahmadu Bello University, Zaria are appreciated for the technical assistance rendered.

\section{Conflict of interest}

Author declares that there is no conflict of interest.

\section{References}

1. Minka NS, Ayo JO. Effects of cold-dry (harmattan) and hot-dry seasons on daily rhythms of rectal and body surface temperatures in sheep and goats in a natural tropical environment. J Circadian Rhythms. 2016;14(1):1-11.

2. Habibu B, Kawu MU, Makun HJ, et al. Seasonal variation in body mass index cardinal physiological variables and serum thyroid hormones profiles in relation to susceptibility to thermal stress in goats kids. Small Rum Res. 2016;145:20-27.

3. Escalda A, Marques M, Silva Carvalho L, et al. Hypothermia-induced haemostatic and biochemical phenomena. An experimental model. Platelets. 1993;4(1):17-22.

4. Van Poucke S, Stevens K, Marcus, AM, et al. Hypothermia: effects on platelet function and hemostasis. Thromb J. 2014;12(1):31.

5. Bazzano M, Giannetto C, Fazio F, et al. Hemostatic profile during late pregnancy and early postpartum period in mares. Theriogenology 2014;81(4):639-643.

6. Spronk HM, Van Der Voort D, Ten Cate H. Blood coagulation and the risk of atherothrombosis: a complex relationship. Thromb J. 2004;2(1):12.

7. Johri P, Nagare S, Swamy KV, et al. An insight into blood clotting disorders in humans. J Comput Biol Bioinform Res. 2011;3(1):8-14.

8. Palta S, Saroa R, Palta A. Overview of the coagulation system. Indian J Anaesth. 2014;58(5):515-523.

9. Yaqub LS, Kawu MU, Ayo JO. Influence of reproductive cycle, sex, age and season on haematologic parameters in domestic animals: A review. $J$ Cell Anim Biol. 2013;7(4):37-43.

10. Habibu B, Kawu M, Makun H, et al. Influences of breed, sex and age on seasonal changes in haematological variables of tropical goat kids. Arch Anim Breed. 2017;60:33-42.

11. Ferdous F, Scott TR. A comparative examination of thrombocyte/platelet immunity. Immunol Lett. 2015;163(1):32-39.

12. Rolinec M, Bíro D, Šimko M, et al. The development of platelets indices in blood of neonatal pigs in early postnatal period. Acta fytotechn zootechn. 2013;16(3):58-60.

13. Schneider L, Mischke R. Platelet variables in healthy dogs: reference intervals and influence of age, breed and sex. Comp Clin Pathol. 2016;25(6):1097-1106.

14. Santucci PM, Branca A, Napoleone M, et al. Body condition scoring of goats in extensive conditions. Goat nutrition. Wageningen, Netherlands: EAAP Publication, Pudoc III; 1991. p. 240-256.

15. Igono MO, Aliu YO. Environmental profile and milk production of Friesian Zubucrosses in Nigerian Guinea Savannah, Int J Biometeorol. 1982;26(2):115-120.
16. Dacie JV, Lewis SM. Practical hematology. 7th ed. London, UK: Churchill Livingstone Edinburg; 1991

17. Lu DC. Effects of heat stress on goat production. Small Rum Res. 1989;2(2):151-162.

18. Egbe Nwiyi TN, Igwenagu E, Samson M. The influence of sex on the haematological values of apparently healthy adult Nigerian Sahel goats. Sokoto J Vet Sci. 2015;13(2):54-58.

19. Sullivan PS, Jackson CW, McDonald TP. Castration decreases thrombocytopoiesis and testosterone restores platelet production in castrated BALB/c mice: evidence that testosterone acts on a bipotential hematopoietic precursor cell. J Lab Clin Med. 1995;125(3):326-333.

20. Panousis NK, Kritsepi Konstantinou M, Giadinis ND, et al. Haematology values and effect of age and reproductive stage onhaematological parameters of Chios sheep. J Hellenic Vet Med Soc. 2007;58(2):124-136.

21. Balduini CL, Noris P. Platelet count and aging. Haematologia. 2014;99(6):953-955

22. Biino G, Santimone I, Minelli C, et al. Age and Sex Related Variations in Platelet Count in Italy: A Proposal of Reference Ranges Based on 40987 Subjects' Data. Plos One. 2013;8(1):e54289.

23. Ishiguro A, Nakahata T, Matsubara K, et al. Age-related changes in thrombopoietin in children: reference interval for serum thrombopoietin levels. Br J Haematol. 1999;106(4):884-888.

24. Okonkwo JC, Okonkwo IF, Ebuh GU. Effect of breed, sex and source within breed on the haematological parameters of the Nigerian goats. Online J Anim Feed Res. 2011;1(1):8-13.

25. Sharma A, Kumar P, Singh M, et al. Haemato-biochemical and endocrine profiling of north western Himalayan Gaddi sheep during various physiological/reproductive phases. Open Vet J. 2015;5(2):103-107.

26. Byers SR, Kramer JW. Normal Hematology of Sheep and Goats. In: Weiss DJ, Wardrop KJ, editors. Schalm's Veterinary Hematology. 6th ed. Lowa, USA: John Wiley \& Sons Ltd; 2010. p. 836-842.

27. Al Hadithy HA, Badawi NM. Determination of serum proteins and glucose concentrations in clinically normal and anemic Awassi sheep. World Vet J. 2015;5(1):1-6.

28. Ahmadi hamedani M, Ghazvinian K, Kokhaei P, et al. Comparison of effects of age and sex on serum protein electrophoretic pattern in onehumped camels (Camelus dromedarius) in Semnan, Iran. Open Vet J. $2014 ; 4(1): 4-8$

29. Zargham Khan M, Muhammad G, Umar A, et al. Preliminary observations on plasma fibrinogen and plasma protein concentrations and on plasma protein:fibrinogen ratios in clinically healthy buffaloes. Vet Res Comm. 1994;18(2):103-107.

30. Chaudhary ZI, Iqbal J, Rashid J. Serum protein electrophoretic pattern in young and adult camels. Aust Vet J. 2003;81(10):625-626.

31. Oramari RAS, Bamerny AO, Zebari HMH. Factors affecting some hematology and serum biochemical parameters in three indigenous sheep breeds. Adv Life Sci Technol. 2014;21:56-62.

32. Kandiel MMM, El Khaiat HM, Mahmoud KG. Changes in some hematobiochemical and hormonal profile in Barki sheep with various reproductive statuses. Small Ruminant Research. 2016;136:87-95.

33. Bayoumi MT, Assad F, Nassar AM, et al. Serum protein electrophoresis in different physiological stages in ewes. World Rev Anim Prod. 1986;22(4):55-58.

34. Mohammadi V, Anassori E, Jafari S. Measure of energy related biochemical metabolites changes during peri-partum period in Makouei breed sheep. Vet Res Forum. 2016;7(1):35-39. 
35. Tharwat M, Ali A, Al Sobayi F. Hematological and biochemical profiles in goats during the transition period. Comp Clin Pathol. 2015;24(1):1-7.

36. Mikhailidis DP, Ganotakis ES. Plasma albumin and platelet function relevance to atherogenesis and thrombosis. Platelets. 1996;7(3):125-137.
37. Arfuso F, Giannetto C, Giudice E, et al. Dynamic modulation of platelet aggregation, albumin and nonesterified fatty acids during physical exercise in Thoroughbred horses. Res Vet Sci. 2016;104:86-91.

38. Rasmussen KC, Højskov M, Johansson, PI, et al. Impact of albumin on coagulation competence and hemorrhage during major surgery a randomized controlled trial. Medicine. 2016;95(9):e2720. 